Original Research Paper

\title{
Introduksi Budidaya Belut Sawah (Monopterus albus) dan Cacing Merah (Lumbricus rubellus) sebagai Pakan Belut di BTN Kendari Permai, Kota Kendari, Provinsi Sulawesi Tenggara
}

\author{
Muhammad Idris ${ }^{1}$, Amirullah $^{2}$, Emiyarti ${ }^{3}$, Sjamsu Alam Lawalle $^{4}$, Ira $^{3}$ \\ ${ }^{1}$ Jurusan Budidiaya Perairan, Fakultas Perikanan dan Ilmu Kelautan, Universitas Oleo, Kendari, Indonesia; \\ ${ }^{2}$ Jurusan Biologi, Jurusan Budidiaya Perairan, Fakultas Perikanan dan Ilmu Kelautan, Universitas Oleo, Kendari, Indonesia; \\ 3 Jurusan Ilmu Kelautan, Jurusan Budidiaya Perairan, Fakultas Perikanan dan Ilmu Kelautan, Universitas Oleo, Kendari, \\ Indonesia; \\ 4 Jurusan Agrobisnis Perikanan, Jurusan Budidiaya Perairan, Fakultas Perikanan dan Ilmu Kelautan, Universitas Oleo, \\ Kendari, Indonesia;
}

https://doi.org/10.29303/jpmpi.v3i2.515

Sitasi: Idris, M., Amirullah., Emiyarti., Lawalle, S. A., \& Ira. (2021). Introduksi Budidaya Belut Sawah (Monopterus albus) dan Cacing Merah (Lumbricus rubellus) sebagai Pakan Belut di BTN Kendari Permai, Kota Kendari, Provinsi Sulawesi Tenggara . Jurnal Pengabdian Magister Pendidikan IPA, 4(2)

\section{Article history}

Received: 05 Januari 2021 Revised: 19 Februari 2020

Accepted: 05 Maret 2021

*Corresponding Author: Muhammad Idris, Jurusan Budidiaya Perairan, Fakultas Perikanan dan Ilmu Kelautan, Universitas Oleo, Kendari, Indonesia

Email: idrisbojosa@uho.ac.id

\begin{abstract}
Telah dilakukan kegiatan Program Kemitraan Masyarakat Internal UHO (PKMI-UHO), untuk mengintroduksi metode budidaya belut sawah (Monopterus albus) baik dengan media lumpur maupun dengan media air bersih, dan budidaya cacing merah sebagai pakan belut sawah, di BTN Kendari Permai, Kota Kendari, Provinsi Sulawesi Tenggara. Pelaksanaan meliputi pelatihan, praktek langsung dan pendirian Demplot (Demonstration Plot) budidaya belut sawah dan budidaya cacing tanah merah. Terdapat dua aspek yang menjadi acuan dalam evaluasi. Aspek proses, terdapat antusiasme yang besar dari warga terhadap pelaksanaan kegiatan. Aspek hasil, mulai dari sosialisasi hingga pelaksanaan demplot, warga menjadi tahu cara budidaya belut sawah dan cacing merah, dan menguasai teknologi tersebut.
\end{abstract}

Keywords: Budidaya, Belut Sawah, Cacing Merah

\section{Pendahuluan}

Sebagian besar masyarakat Sulawesi Tenggara, secara tradisional mengenal belut sawah (Monopterus albus) sebagai sumber protein hewani yang nikmat dikonsumsi. Menurut Yin dan Liu (2010), belut sawah mengandung protein, asam amino esensial seperti lysinus dan metionin, fosfor, serat kasar, dan kalsium. Beberapa etnik yang mendiami provinsi ini, memiliki kekayaan kuliner yang berbahan utama komoditas ini. Namun demikian, belum ada upaya-upaya untuk membudidayakan komoditas ini untuk tujuan komersial. Umumnya, belut yang dikonsumsi dan dijual di pasaran bersumber dari hasil penangkapan di alam. Padahal, budidaya belut tidaklah sulit, bahkan dapat dilakukan pada lahan-lahan sempit seperti halaman rumah yang sempit. M. albus dapat beradaptasi dengan kondisi lingkungan yang sulit lebih dari ikan lain (Starnes et al, 1998). Belut ini juga dapar melewati tanah basah untuk migrasi (Hill dan Watson, 2007).

Teknik pembudidayaan yang berkembang di sentra-sentra budidaya belut yang ada di Jawa Timur, Jawa Tengah, Jawa Barat telah mengembangkan berbagai metode yang dapat diterapkan pada halaman rumah yang sempit. Antara lain budidaya belut dalam drum bekas, terpal dan lain-lain. Introduksi metode budidaya ini pada masyarakat Sulawesi Tenggara, perlu dilakukan, mengingat metode ini dapat menjadi alternatif usaha untuk meningkatkan penghasilan keluarga. Apalagi, harga komoditas ini, khususnya 
di Jawa, lebih tinggi dibandingkan dengan harga ikan konsumsi lainnya. Sebagai ilustrasi, harga belut mencapai Rp. 40.000,-/kg, sedangkan harga ikan bandeng Rp. 20.000,-/kg. Potensi pasar pun sangat tinggi. Untuk kebutuhan lokal saja, dapat diilustrasikan dengan perhitungan sebagai berikut. Jumlah penduduk Kota Kendari, berdasarkan Kota Kendari dalam Angka 2020, sebanyak 392.830 jiwa (Data 2019) (Anonimous, 2020b). Jika 0,5\% saja dari penduduk Kota Kendari yang mengkonsumsi belut, dan masing-masing mengkonsumsi 100 gr/hari, diperlukan pasokan belut sebanyak 196,415 $\mathrm{kg} /$ per hari. Pangsa pasar tersebut akan lebih besar jika yang masuk hitungan adalah penduduk Sulawesi Tenggara yang jumlahnya 2.704 .737 jiwa (Data tahun 2019) (Anonimous, 2020a). Kebutuhan harian untuk provinsi, berdasarkan perhitungan yang sama, akan menjadi 1,35 ton/hari. Potensi pasar di Sulawesi Tenggara, bahkan ke provinsi tetangga seperti Sulawesi Selatan, menjadi sangat terbuka mengingat beberapa etnik yang mendiami provinsi ini sangat menggemari sumber protein hewani tersebut, sementara di sisi lain, suplai lokal juga belum mencukupi.

Pandemi Covid-19 selain berdampak terhadap kesehatan juga berdampak terhadap sosial ekonomi masyarakat khususnya masyarakat dengan penghasilan yang sudah jauh berkurang karena faktor usia, yakni kalangan pensiunan. Pada kondisi sebelum Covid-19, beberapa pensiunan PNS memperoleh penghasilan tambahan melalui warung, ojek, dan jasa yang omsetnya menurun selama pandemi Covid-19. Akibatnya, terjadi penurunan atau bahkan kehilangan pendapatan, yang pada gilirannya mengakibatkan penurunan daya beli khususnya terhadap sumber protein. Sementara itu, pada masa pandemi Covid-19, setiap warga diharapkan menjaga dan meningkatkan imunnya melalui konsumsi nutrisi yang salah satunya adalah protein sedangkan di satu sisi kemampuan daya beli mengalami penurunan.

Pakan belut yang digunakan adalah cacing tanah merah (Lumbricus rubellus). Cacing tanah ini mempunyai banyak kelebihan dibanding cacing jenis lain. Kelebihan dari cacing ini adalah tidak berbau, cepat berkembang biak, tumbuh subur, mempunyai ketahanan hidup yang tinggi, mudah beradaptasi dengan berbagai media yang dipergunakan. Selain itu, L. Rubellus merupakan sumber protein sangat tinggi dengan kadar sekitar $76 \%$. Kadar ini lebih tinggi dibandingkan daging mamalia (65\%) atau ikan (50\%). Cacing tanah juga mengandung beberapa kadar komponen lain, seperti $17 \%$ karbohidrat, $45 \%$ lemak,dan abu 1,5 $\%$ (Flora, 2014). Selain itu ekstrak cacing tanah merah mengandung sifat antibakteri yang dapat menghambat pertumbuhan bakteri patogen baik dari bakteri gram positif maupun gram negatif (Garrido, 2004). Karena itu, atas dasar itu, maka diadakanlah kegiatan Program Kemitraan Masyarakat budidaya belut sawah (Monopterus albus) dan Cacing Tanah Merah (Lumbricus rubellus) sebagai Pakan Belut di BTN Kendari Permai, Kelurahan Padaleu Kecamatan Kambu Kota Kendari Sulawesi Tenggara.

\section{Metode}

\section{Waktu dan Lokasi}

PKMI-UHO ini dilaksanakan dari bulan Agustus hingga November 2020. Lokasi pelaksanaan kegiatan di BTN Kendari Permai, Kelurahan Padaleu, Kecamatan Kambu, Kota Kendari Provinsi Sulawesi Tenggara.

\section{Metode Pelaksanaan}

Mitra pada kegiatan ini adalah pensiunan PNS yang berada di dasa wisma RW 1 dan RW 2, Kelurahan Padaleu, yang juga berada di Perumahan BTN Kendari Permai. Namun, kegiatan ini tidak menutup kesempatan kepada warga lain yang ingin belajar dan mempraktekkan metode budidaya belut sawah dan cacing merah. Bentuk kegiatan adalah sebagai berikut:

\section{a). Kegiatan Non Fisik}

\section{Pelatihan Mitra}

Pelatihan mitra dilakukan kepada kedua mitra,kelompok budidaya belut sawah dan kelompok budidaya cacing tanah merah untuk pakan belut. Materi yang diberikan antara lain sebagai berikut:

(1) Introduksi belut sawah: biologi, prospek budidaya, dan agribisnis belut sawah Indonesia

(2) Jenis dan persyaratan media yang digunakan dalam budidaya belut sawah dan cacing tanah merah

(3) Komposisi media lumpur pada budidaya belut sawah

(4) Teknik pembuatan media lumpur untuk budidaya belut sawah

(5) Teknik pembuatan media untuk budidaya cacing tanah merah 
(6) Pengontrolan dan pengecekan kematangan media lumpur untuk budidaya belut sawah

(7) Kriteria dalam seleksi benih yang layak untuk dibudidayakan

(8) Penanganan belut sawah yang lolos seleksi sebagai benih

(9) Aklimasi belut sawah pada media budidaya

(10) Pengenalan jenis pakan yang dapat diberikan kepada belut sawah

(11) Metode budidaya cacing tanah merah sebagai pakan belut sawah

(12) Teknik fermentasi sampah dapur untuk pakan cacing tanah merah

(13) Metode adaptasi pakan kepada belut sawah

(14) Manajemen pemberian pakan belut sawah

(15) Metode pengontrolan berkala kondisi belut sawah, yang meliputi kondisi kesehatan, pertumbuhan dan tingkat kelangsungan hidup

(16) Metode grading size belut sawah dan pemindahannya ke kolam yang sesuai dengan ukurannya

(17) Metode panen selektif untuk menghasilkan belut sawah yang diterima pasar

2. Kegiatan pendampingan

Kegiatan pendampingan kepada mitra yang melakukan pembudidayaan belut sawah, dilakukan selama berlangsungnya kegiatan budidaya. Tim pelaksana kegiatan, baik secara bersama-sama maupun bergiliran, berkunjung ke lokasi untuk mendampingi mitra dalam kegiatannya. Dua orang, yakni ketua tim dan satu anggota tim, beralamat di BTN Kendari Permai, sehingga pendampingan akan berlangsung dengan mudah.

\section{b). Kegiatan Fisik}

1. Demplot Budidaya Belut Sawah dan Cacing Tanah Merah untuk Pakan Belut Sawah

Kegiatan PKMI-UHO ini menyediakan Demplot (Demonstration Plot) budidaya belut sawah dan budidaya cacing tanah merah sebagai pakan belut, sebagai sarana belajar bagi mitra serta masyarakat yang bermukim di Kompleks Perumahan BTN Kendari Permai. Demplot berlokasi di BTN Kendari Permai Blok B3 No. 17. Demplot budidaya belut sawah berupa 1 buah bak ibc terbuat dari plastik dan dilengkapi dengan rangka besi, dengan volume 1 ton, yang dipotong jadi dua. Demplot budidaya cacing tanah merah berupa bekas karung beras kapasitas $50 \mathrm{~kg}$ sebanyak dua buah.

\section{Rancangan Evaluasi}

Untuk mengevaluasi kegiatan PKMI ini, digunakan rancangan evaluasi dengan dua aspek, yakni proses pelaksanaan dan hasil yang dicapai. Pada aspek proses, penilaian ditujukan kepada rasa ingin tahu, antusiasme, dan keinginan menerapkan introduksi teknologi. Pada aspek hasil, yang dinilai adalah pemahaman, penguasaan, akan introduksi teknologi, sehingga dapat juga menerapkan sendiri teknologinya.

\section{Hasil dan Pembahasan}

\section{A. Pelaksanaan Program Kegiatan}

1. Kegiatan Non Fisik

\section{a). Pelatihan Mitra}

Sehubungan dengan pandemi Covid-19, mengingat pensiunan PNS adalah kelompok umur yang rentan, sehingga harus memperhatikan protokol kesehatan, pelatihan dalam bentuk pengumpulan orang tidak dilakukan. Penyampaian materi mengandalkan pelayanan individual kepada warga yang sempat berkunjung ke lokasi Demplot. Pelaksanaan kegiatan seperti pemberian pakan kepada cacing, karantina dan treatmen calon bibit belut, seleksi calon bibit belut menjadi bibit, didokumentasi dalam bentuk video sehingga dapat dibagikan kepada warna yang berminat. Pembuatan fermentasi bahan-bahan pembentuk lumpur untuk budidaya belut sawah media lumpur (seperti jerami, gedebog pisang, serta kotoran hewan (sapi), juga didokumentasikan.

\section{b) Kegiatan Pendampingan}

Bibit belut sawah yang diperoleh dari pengumpul, ditampung dalam tong plastik berkapasitas 120 liter, yang dijadikan sebagai bak karantina. Selama proses karantina, diterapkan penambahan formulasi herbal yang jadi temuan pada penelitian sebelumnya, dengan konsentrasi $50 \mathrm{ml}$ per 1 liter air. Selama proses karantina ini, dan seleksi bibit, dilakukan pendampingan kepada mitra. Pendampingan mitra tidak menjadi masalah karena dua orang dari tim pelaksana adalah juga warga perumahan BTN Kendari Permai. 
2. Kegiatan Fisik

a. Demplot Budidaya Belut Sawah dan Cacing Tanah Merah untuk Pakan Belut Sawah

Kegiatan percontohan budidaya belut sawah dilakukan dengan dua metode, yakni metode dengan media lumpur, dan metode dengan media tanpa lumpur. Sementara itu, budidaya cacing tanah merah dilakukan menggunakan media cocopeat. Pakan cacing yang diberikan, adalah sisa-sisa dapur yang diberikan dengan tiga cara. Pertama, pemberian langsung. Sisa dapur langsung diberikan ke dalam media cacing. Proses pembusukan berlangsung dalam media. Kedua, sisa dapur dibiarkan membusuk di luar media. Nanti setelah membusuk, baru diberikan ke dalam media. Ketiga, sisa dapur difermentasikan di luar media dengan bantuan fermentor komersial yang tersedia di pasaran. Namun dari ketiga cara tersebut, cara yang banyak diterapkan mitra adalah dengan pemberian langsung ke media cacing tanah.

\section{B. Monitoring dan Evaluasi Program}

\section{Monitoring}

Monitoring pelaksanaan demplot dilakukan dengan kehadiran di lokasi pelaksanaan demplot. Ketika terjadi masalah, misalnya cacing banyak yang keluar meninggalkan media, mitra diberi solusi dan penjelasan. Pemberian sisa dapur secara langsung ke media cacing, akan menyebabkan proses pembusukan yang berlangsung dalam media. Proses ini menimbulkan panas yang diduga menjadi penyebab cacing tidak nyaman dan meninggalkan media. Solusinya, mitra diminta membolak-balik media agar panas yang terperangkap dalam media dapat lepas. Tindakan ini cukup efektif, karena setelah itu tidak ada lagi cacing yang keluar dari media.

Monitoring yang sekaligus pendampingan, juga dilakukan pada kegiatan budidaya belut sawah, khususnya pada proses fermentasi bahanbahan pembentuk lumpur seperti jerami padi, gedebog pisang, dan kotoran hewan (kotoran sapi). Proses ini memang menjadi tahapan yang krusial karena jika salah dalam penilaian fermentasi, pada saat dimasukkan ke dalam bak budidaya, bisa menyebabkan kematian pada belut karena bahan-bahan tersebut masih mengandung banyak amoniak. Tahap ini juga sangat krusial sehingga monitoring menjadi sekaligus pendampingan dari tim pelaksana.

\section{Evaluasi}

Dari aspek proses, kegiatan ini ditujukan kepada anggota masyarakat yang tidak memiliki background petani ikan atau nelayan. Khalayak sasaran adalah pensiunan PNS yang memiliki pendidikan sehingga bersifat lebih kritis. Ada kesan bahwa khalayak sasaran menunggu dulu pembuktian bahwa demplot ini dapat dilaksanakan hingga panen. Sementara itu, tim pelaksana adalah peneliti belut sawah, dan cacing tanah yang telah berpengalaman dalam budidaya. Dengan demikian, terdapat pertemuan dari aspek proses, khalayak sasaran terlihat hati-hati menyikapi introduksi teknologi. Dengan demikian, demonstration plot merupakan kegiatan yang paling penting dalam kegiatan ini, karena menjadi pembuktian bagi khalayak terhadap kelayakan dari teknologi yang diintroduksikan.

Dari aspek hasil, kegiatan ini memberikan hasil berupa pengetahuan dan keterampilan pada khalayak sasaran. Latar belakang suku dari khalayak sasaran, dengan beberapa suku secara tradisional telah mengenal belut sawah sebagai komoditas pangan yang disukai, menjadi modal pengetahuan bagi khalayak sasaran. Dengan demikian, setelah kegiatan ini berlangsung, $100 \%$ khalayak sasaran mengetahui bahwa belut sawah dapat dibudidayakan, mau makan pakan berupa cacing tanah, dan penambahan bobot selama pemeliharaan, dapat terjadi.

\section{Kendala dan Keberlanjutan Program}

Salah satu kendala dalam kegiatan ini adalah sumber bibit yang masih diperoleh dari alam, dengan cara penangkapan yang mungkin tidak ramah lingkungan seperti penggunaan stroom. Hal ini akan membuat tingkat kematian tinggi. Jika kematian berlangsung terus menerus, semangat mitra bisa merosot dan kegiatan budidaya belut menjadi tidak menarik minat lagi. Karena itu, upaya untuk memperoleh bibit belut yang ditangkap tidak dengan menggunakan stroom, menjadi solusi untuk mengantisipasi ancaman keberlanjutan kegiatan. 


\section{Kesimpulan}

Kegiatan ini menunjukkan, bahwa masyarakat sangat memerlukan introduksi teknologi yang diikuti oleh pembuktian bahwa teknologi yang diintroduksikan sukses menghasilkan panen. Kegiatan yang hanya bersifat penyuluhan dan bimbingan teknis tanpa pembuktian bahwa teknologi tersebut layak dan proven. Tanpa pembuktian tersebut, masyarakat berpendidikan seperti pensiunan PNS yang tinggal di perkotaan, sulit diajak untuk menerapkan suatu teknologi.

\section{Daftar Pustaka}

Anonymous, 2020a. Jumlah Penduduk Menurut Kelompok Umur dan Jenis Kelamin diSulawesi Tenggara, 2019. Badan Pusat Statistik Sulawesi Tenggara. https://sultra.bps.go.id/statictable/2020/03/29 /2694/jumlah-penduduk-menurut-kelompokumur-dan-jenis-kelamin-di-sulawesitenggara-2019.html. Download pada 2 Agustus 2020.

Anonimous, 2020b. Kota Kendari dalam Angka 2020. Badan Pusat Statistik Kota Kendari. https://kendarikota.bps.go.id/publication/202 0/04/27/92547d4e1782f96d6ac289c7/kotakendari-dalam-angka-2020.html. Download pada 2 Agustus 2020

Flora E. 2014. Manfaat dan Khasiat Cacing Tanah. http://indonesian-herbal.

Blogspot.com/2014/03/manfaat-dan-khasiatcacing-tanah.html. Diakses tanggal 27 November 2020.

Garrido AG, Poli de Figueiredo LF, Rocha de Silva M. Experimental models of sepsis and septic shock: an over-view. Acta Cir Bras. 2004; 19(2): 2 - 8 . DOI: $10.1590 /$ S010286502004000200001.

Hill JE, Watson CA (2007) Diet of the nonindigenous Asian swamp eel in tropical ornamental aquaculture ponds in WestCentral Florida. North American Journal of Aquacul-ture 69: 139 - 146

Starnes WC, Bryant RT, Greer GC. 1998. Perilous experiment: the Asian rice eel in Georgia. Georgia. Natural Georgia Series 7: 60-70.

Yin S, Liu Y. 2010. Compositions and functions of the hatching froth from ricefield eel
(Monopterus albus). Journal of Fish Physiology and Biochemistry 36: $195-200$. doi: 10.1007/s10695-008-9274-6. 